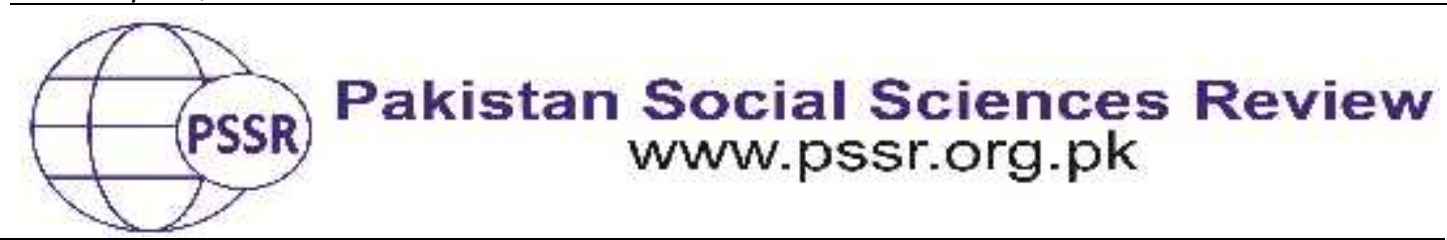

RESEARCH PAPER

\title{
An Empirical Study on Linkage between Monetary Instrument and Economic Growth in Pakistan: A New Evidence
}

\author{
Farhana Nosheen ${ }^{1}$ Hina Ali *2 Nazia Nasir ${ }^{3}$
}

1. Assistant Professor, Department of Economics, Govt. Associate College for Women Muzafarabad, Multan, Punjab, Pakistan

2. Assistant professor, Department of Economics, The Women University Multan, Punjab, Pakistan

3. Research Scholar, Department of Economics, The Women University Multan, Punjab, Pakistan

\begin{tabular}{|c|c|}
\hline & \multirow{14}{*}{$\begin{array}{l}\text { This research is going to analyses the linkages between the } \\
\text { monetary policy instruments which have a great influence on } \\
\text { economic growth in Pakistan. Monetary policy a kind of } \\
\text { demand management policy that deals with the stabilization } \\
\text { and the economic growth of the economy with a high level of } \\
\text { employment and a moderate price level. Analysis has been } \\
\text { done by utilizing the time series data for the period 1975-2019. } \\
\text { By testing the time series for unit root we have estimated the } \\
\text { relationship with the ARDL model. The study has used Gross } \\
\text { domestic product growth rate, Consumption expenditure, } \\
\text { Inflation, Gross domestic saving, Gross national expenditure, } \\
\text { money supply M2. It has been concluded that expansion in } \\
\text { money supply and employment opportunities has a positive } \\
\text { impact on growth both in the long and short run. It has been } \\
\text { suggested govt. must consider the monetary policy to control } \\
\text { the economic activity and to stabilize the economy both in the } \\
\text { short and in the long run. }\end{array}$} \\
\hline & \\
\hline & \\
\hline & \\
\hline & \\
\hline & \\
\hline & \\
\hline & \\
\hline & \\
\hline & \\
\hline & \\
\hline & \\
\hline & \\
\hline & \\
\hline
\end{tabular}

\section{Introduction}

Monetary policy has a great influence on the economy since world development through modernization. These policies are implemented in an economy to control the circulation of money in all sectors of the economy. And also to upsurge the GDP growth rate to ensure stability and productivity in a single nation. Monetary policy is a method by which the power of determinant of a country regulates the money supply. Often directing the amount of inflation or rate of interest to guarantee price constancy and the general belief in the currency. Moreover, this policy aims to habitually subsidize economic growth and stability, decrease unemployment, and preserve the expected rate of exchange with other currencies. Monetary policy customs a diversity of tackles to control both of these, to 
stimulus outcomes like economic growth (GDP), inflation, rate of exchange with additional currencies, and unemployment. Where currency is underneath domination of issuance, or where there is a normalized system of supplying currency through banks that are tangled to a central bank, the monetary organization has the authority to modify the money supply Range of monetary policy techniques accessible to accomplish the following end rising interest rates by permission; decreasing the monetary sordid and increasing stand-in necessities. Even before the 1970's the Bretton Woods system motionlessly safeguarded that many of the nations would form the dual policies individually. In other illustrations, monetary policy strength in its place entails the aiming of a particular exchange rate comparative to some external currency or else qualified to gold.

If a worker supposes prices to be extraordinary in the future, he or she will put together a pay agreement with high pay to equal these values. Hence, the anticipations of lesser wages replicated in wage-situation performance between workers and managers (minor incomes since amounts are anticipated to be lower). To attain low glassy inflation, legislators have reliable statements; that is secluded agents must trust that these statements will imitate genuine upcoming policy. If a statement near squat-level inflation goal is formulated not supposed by isolated mediators, wage-location has been antedate from head to foot-level inflation and so salaries advanced and hence price rises.

Monetary policy as a decision-making process or the rule of the coin is normally in the hands of the organization with the seignior stage. Throughout the era of 1870-1920, the manufacturing states set up essential banking organizations, with one of the last existence of the Centralized Standby in 1913. Monetary economists resisted that the hoard of money growth can disturb the command of economy involved "Milton Friedman" concepts premature in his profession encouraged administration economical shortfalls through downturns be supported in alike quantity money construction to help inspire cumulative request yield. Later he backed simply growing the monetary supply at a squat, unbroken rate, as the best way of keeping low- inflation and constant productivity. Nevertheless, when U.S. Federal Standby Chairman Paul Volcker strained this policy, opening October 1979, initially unfeasible because of the extremely unbalanced association between monetary collections and other macroeconomic variables. Even Milton Friedman earlier accepted that through money supply directing less valuable, he wished. 
0

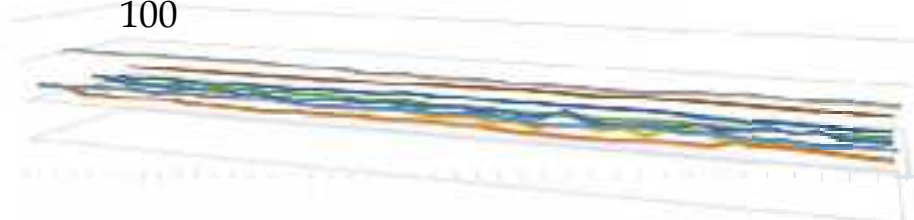

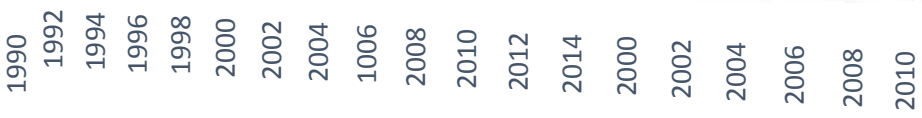

$$
\text { M2 M2INF GNE CF GDP GDS EMP }
$$

Figure1 Trend of Dependent and Independent Variables

Source: Pakistan Economic Survey and World development indicators.

\section{Literature Review}

The monetary policy provides a transmission mechanism for economic growth. It also maintains the stability in prices. These policies and instruments have a great impact on conditions of finance, cost, availability of credit in an economy, and rate of specific risk assumed by banks. It has also a great influence on inflation, prices of goods and services, investment, consumption, exchange rate, and trade activities maintained by an economy.

\section{Studies Based on Developed Countries}

King and Levine (1993) investigated the Finance and Growth that is published by the Oxford University Press. They researched the view of an economist (Schumpeter 1911) that the financial system can increase the development of economies. They used the data of 80 countries from 1960-1989 and used the different techniques to assess that either financial development is firmly related to per capita economic growth or not. They concluded that both economic growth and financial system are "Overstressed" and interrelated by aggregation of capital (physical) and enhance the productivity with which an economy utilizes the capital (labor force). Levine (2002) examined the financial expansion and economic evolution; "Opinions and Schedule." He investigated the different opinions of different economists regarding the financial sector and economic growth. According to his view, economic development increased the demand for specific kinds of financial preparatory measures. He also researched on the comments of some other economists who believe that there was no connection between financial growth and economic growth, but from all of his discussion, he resulted that with huge qualifications of reasons of theories and necessary demonstration recommended that both financial development and economic growth had a positive first-order relationship. 
Papademos (2003) studied the contribution of monetary policy to Economic Growth on 30years old data to lighten out the important and topical issues in the economy. They investigated the economic growth in Europe to determine the factors that play a vital role to achieve sustainable growth. He discussed the contribution of monetary policies to economic growth as well as some fundamental rules and issues concern with monetary policies in determining growth in an economy to distinguish between continual and impermanent effects. Sherraden et. al (2011) evaluated the wealth account liberalization, financial complexity, and economic advancement. From the data of cross-piece realms over the period 1976-1995 he discovered that developed countries had a tremendous increase in the financial sector along with greater economic growth. They derived the unsuccessful capital measures to improve the strength of financial potential among developing countries to suggest the policies to increase capital measures.

Morse (2013) worked on scientific accretion and industrial progress: dissimilarity between industrialized and developing nations. He studied the data of the 1980s to show the impact of the long-run significance of pertaining technologies and their changes. He gave the idea of agricultural location-specific technology then the industrial sector. They applied cross-sectional techniques on data and concluded that in developing countries new technologies such as machinery, instructions of operations, applied industrial sector for improvement in the efficiency in productivity for the unsuitable production experiences.

\section{Studies Based on Developing Countries}

The new monetary development framework and investigated the role of FDI that either plays a vital role in the process of economic growth in developing economies. They used the cross-sectional data of about 46 countries (underdeveloped countries). Because of the less conceptual frame and succinct measurable hypothesis, the connection between economic growth and FDI is very few speculative judgments (Contessi \& Weinberger 2009). Altar (2003) investigated fiscal policy, monetary policies, and economic growth and studied the great relationship between fiscal and monetary policy, and both had a strong effect on economic growth. They researched the previous reports of (Romer, 1986; Lucas, 1988), and further explained the concept of those economists. They stated that the nominal money supply led to a huge effect on the rate of growth in long-run activities. The conclusion of the work claimed the forceful equation of consumption depends on both rates of inflation and interest rate. Jain (2001) investigated the connection between monetary policy, investment in South Africa and studied the economic growth model forced by the treatment of monetary. They observed the empirical result of Post Keynesian and monetary policy. Interest rate, cost of capital, nominal exchange rate, demand deposits, and bank liabilities were leading variables of the study. They applied ADF unit root tests to check the significance. They discussed issues of growth, investment, monetary policies, and their interconnection. According to them; "theoretically and empirically defined linkages hold out 
possibilities that monetary policy could be perused more beneficially towards the realization of investment and desired growth objectives of the economy". Baghebo and stephen (2014) empirically examined the monetary policy and economic progress in Nigeria through variables such as GDP, inflation, and BOP also known as macroeconomics. They selected the data from 1980-2011. They applied the OLS technique (Regression analysis) over FEE, rapid EG price stability, and external balance. According to them, in a highly inflated economy, most of the investors enforced the short-term investment which is required forehand for development \& economic growth. According to their concluded result, the central bank of any country plays a vital role to regulate the State of the economy and productivity level.

Dimitrijević and Lovre (2013) wrote an essay on monetary policy \& economic growth. According to $\backslash$ their tremendous work, the reduction in credit activity decrement in domestic product and direct investment by foreigners was caused by a failure in economic growth so they selected it as a task to find out such an environment that is suitable for economic growth. The main aim of that paper was "Either it is conceivable to use fiscal policy and credit movement as the means of long-term economic growth, and if so, under which condition". They took the "Friedman Quantity theory of Money" which is MV=PY. In the end, the conclusion stated as neutral money was esteemed as existing merely by consent in the long-run economy. Masnan, Shaari, and Hussain (2013) evaluated the rapport among penny supply, economic progression, and inflation. They took the data of Malaysia, Indonesia \& Singapore from "1980 to 2010". They took inflation, money supply, GDP as variables and concluded that money supply could influence economic growth because if the Government of Malaysia and Singapore tried to upsurge the source of money. The increment in the money supply could create inflation in the economy except for the growth. Fasanya, Onakoya, and Agboluaje (2013) investigated that, does monetary policy stimulates the pecuniary growth of Nigeria? For that purpose, they took the data from 1975 to 2010 and use the error connection model to errordependent variables. They took inflation degree, argument rate, and peripheral fallback as a noteworthy instrument of monetary policy. They also used the IS-LM Keynesian function to formulate the empirical model and applied the ADF \& PP test to ignore the suspicious regression on data of the Central Bank of Nigeria and concluded that the policy variables that were selected had both nominal and real effects by the monetary policy.

Kamaan and Nyamongo's (2014) research on the consequence of monetary policy on economic tumor Kenya. The impact of substitutes of monetary policy identified that CBR had negative and insignificant in the output while after four months it became insignificant and positive. In that study, they suggested that the central bank of Kenya should impose such policies to help to reduce the level of inflation, interest rate, and to point up economic growth. They used the VAR an nequation n-variable linear model that stands for the auto-regression model. That type of model was used to analyze the policies, interference of structure, forecasting approach, and approach data description. All they concluded that "The interest rate 
channel is the most operational channel of monetary policy transmission on inflation in Kenya".

Twinoburyo and Odhiambo (2018) studied the bearing of monetary strategy on economic growth and applied Dickey-Fuller and Phillips Person Unit root test, on time series data to check out the stationary. To judge the short-term and long-term driving forces of detected variables, they suggested increasing the monetary policy to enhance the investment with in-country also in foreign countries to gain a stable economic growth. They specified their model as the GDP (depend) to the function money supply, repo rate, CPI, exchange rate. They concluded significant cointegration that all selected variables had a positive impact on GDP but they also stated that inflation is only significant.

\section{Studies Based on Pakistan}

Chaudhry, Malik, and Faridi (2010) investigated the reality and countryside of the linkage between rising and economic growth. He researched that they both had a long-lasting relation in history. He also commented that the money of economists took inflation as necessary for growth in the economy while many of the believers of monetary stated as the harmful determinant for economic development. There were two appearances of his conclusion that what kind of relationship exists among them and in what direction the relation of cause and effect actual being? Qayyum's (2006) research on money inflation and growth in Pakistan and investigated the connection between growth, inflation, and the excess supply of money as well as also tested the monetary policy effects and occurrence in Pakistan. He recommended that inflation (explicit and implicit) both types are attempted by the State Bank of Pakistan to control the monetary policies. He used the Theory of Quantitative money to distinguish the relationship between the supply of money, velocity of money, price, and real income and resulted from the money supply had the foremost factor of causing inflation in Pakistan.

Hameed (2010) worked on the Impacts of monetary policy on GDP on 30 years data of Pakistan through variables like the gross domestic product, the money source, interest speed, inflation proportion, and analysis suggested that there was an interconnection between the monetary policy and GDP. They suggested for the State Bank of Pakistan that they should "Secure monetary stability and soundness of the financial system." Nouri and Samimi(2011) evaluated the impact of Regulatory Policy on budget growth as well as GDP and money supply both had a close relationship. They adopted the ordinary least square method and studied the data of the central bank from 1974 to 2008. They also applied the Hickman IS-LM analysis to show the effectiveness of monetary policies on economic growth. They took GDP as the dependent variable and Labor growth rate, rate of disseminating, government expenditures to GDP ( ratio of amassed savings to GDP), growth rate of interest, money supply. According to their results, there was a significant and positive relationship between money supply economic growth. 
Gul, Mughal, and Rahim(2012) studied the association between monetary gadgets and economic growth by applying the OLS technique to check the relationship between monetary policies, price stability and identified the affiliation among the economic growth and monetary policy by the influence of effects and instruments of monetary policy decisions. According to them, the monetary policy had a great influence on aggregate demand \& aggregate supply accordingly. According to them, GDP refers to household consumption, investment, government spending, and current accounting. They took the sample from 1995 to 2010 and output as a dependent variable while inflation, money supply, interchange rate, curiosity rate as an independent variable. Mabrouk and Hassan (2012) worked on monetarist policy and economic tumor in Pakistan and explored the causality relationship and co-integration between the indications. They also influenced the short-run and long-run relationships among them. They concluded that financial depth, budget deficits, and the exchange rate had an elastic and significant influence on real GDP and caused bi-directionally each other also GDP had caused by financial seriousness, local recognition, and budget deficit units directionally. According to this research, the policy of price stability helped the value of money to be stable and overcome the fluctuations and remove the income inequalities by bringing stability to the economy. They took GDP money and quasi money as a fraction of GDP, domestic credit to private sector \% GDP, real exchange rate budget deficits as \% GDP.

\section{Material and Methods}

In this study, we consider these variables like GDP are dependent and all others are independent variables. We examined the role of our explained variable who accepts the effect of explanatory variables. Further discussion is given below.

\section{Model Specification}

Ourmodelcanbe formulated as follow

$$
\mathrm{GDP}=\beta_{0}+\beta_{1}(\mathrm{CF})+\beta_{2}(\mathrm{INF})+\beta_{3}(\mathrm{EMP})+\beta_{4}(\mathrm{GDS})+\beta_{5}(\mathrm{GNE})+\beta_{6}\left(M_{2}\right)+\varepsilon
$$

Where sign represent

GDP $=$ Gross Domestic Product

$\mathrm{CF}=$ Consumption Function

$\mathrm{INF}=$ inflation

$\mathrm{EMP}=$ Employment

GDS $=$ Gross Domestic Saving

GNE $=$ Gross National Expenditure 
$\mathrm{M}_{2}=$ Money Supply

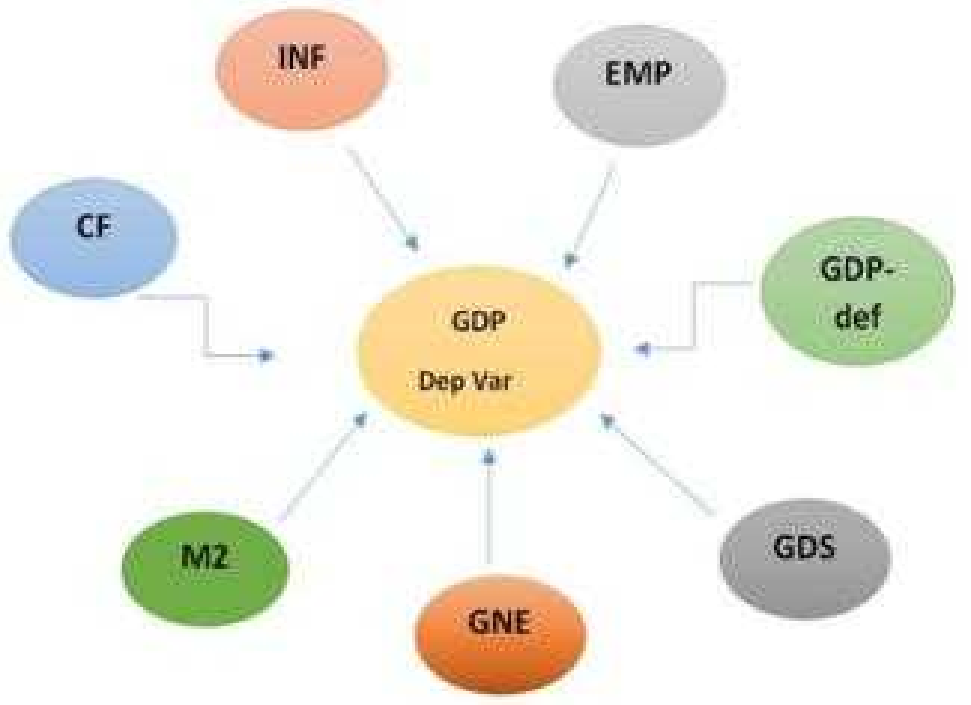

Figure 4: Model of Dependent and Independent Variables

In our above model, one can easily determine the dependent and independent variables. In our model, the middlemost is our explained variable, and all in the oval-shaped round edit display the explanatory variables.

\section{Description of Variables}

Here is some description of the variables. Which can define the role and importance of the selected variables in the whole economy?

\section{Gross Domestic Product}

GDP is a monetary cost of those products available in the economy for the use of consumers it adds up the values of all produced goods and services in a specific period. It includes all goods and services produced in a country within a specific period (usually within a year). Gross Domestic Product can be determined as

(a) Income Approach

(b) Expenditure Approach

(c) Production Approach.

The Production Approach, it calculated all types of goods that formed in a country. Income Approach it is considered that the income of the producer must equal to their production. In the Expenditure Approach, it is measured that customers must purchase all goods. GDP is taken as a dependent variable because every variable has an impact on gross domestic product. In Gross Domestic Product every type of goods and services included that is collected from every sector of the 
economy such as from the agriculture sector, industrial sector, private sector, government sector, financial sector, as well as transport, communication, and foreign sector.

\section{Consumption}

Consumption refers to the goods and services which are used by human beings to fulfill their basic needs or desires. Consumption has two components.

a) Private consumption

b) Public consumption

The term private consumption refers to the consumption of individuals. That they consumed to fulfill their basic needs and desires from their income. Public consumption refers to the consumption of the government sector which they consumed on social welfare, education health sector, and public wellbeing. These are the final expenditures of the goods and services and are normally used to find out the final demand as to the fiscal year.

\section{Inflation}

The average and consistent increase in the price level is known as inflation. In this study, Inflation is used as an independent variable. Inflation means a price rise. By increasing the price level the value of currency reduces. This situation is not suitable for the economy because it reduces the purchasing power of consumers. Consumer Price Index (CPI) is used as an indicator to measure the inflation rate. Inflation is also known as deflation. By inflation the prices of each good and services rise in the economy and the income level of the consumers remains the same. So the consumption of luxury goods and the unproductive expenditures decline. It hurts the gross domestic product in this study because in case of the rise in prices the consumption level of the consumer reduces so that the government earning in form of imposes taxes declines so this situation is not suitable for economic growth.

\section{Employment}

Anactivitywhichisnormallyacquiredtoearnsomethinglikemeanstoliveinasocie ty.This is the state of apers on which is employed in some kind of paid business and laboring etc. employment also refers to the people occupied for compensation or in a family-owned initiative. Employment is an explicit procedure of work in which the workers achieve their labor for someone else in return for remuneration. The employment rate measures the fragment of a working adult who is engaged in a compensating spot. The employment rate is used as an indicator to measure the participation of the labor force in the economy. 


\section{Gross Domestic Saving}

When we subtract the final consumptions from the overall rate of GDP, then we can get our GDS. It includes all the savings from all sectors of the economy, like a house (domestic savings) private business sector $\mathrm{s}$ and government sectors, etc. these savings play a very important role in the process of investment that is beneficial for the economy. Higher the saving rate higher will be the investment and the efficiency of the economy improved. Thus gross domestic savings are necessary for economic growth.

\section{Gross National Expenditure}

GNE is the sum of all those expenditures that are made by the government throughout the year and those consumptions or spending's that are by the household sector. Gross National Expenditure has also denoted the sum of all expenses on consumption and investment plus government spending on goods and services and net exports. The term of net exports indicates the difference between exports and imports.

\section{Money Supply}

Quasi money or simply M2 are those kinds of liquid assets that can be easily transformed into currency at the time of requirement. It is also known as Near Money. Money Supply means the total amount of currency in circulation. It may include currency, coins, bank deposits, bonds, etc. The money supply is used as an independent variable in this study and hurts Gross Domestic Product. An increase in money supply is not suitable for the economy.

Sometimes when government deficit condition has appeared then the expenditure exceeds the earning and in this situation government forces the state bank to print money without any guarantee and the money supply increased in the economy and the interest rate declines it is beneficial for the investors because they paid less for the use of money but this situation is not suitable for the economy because they gain less and their earning are declined.

Table 1

Description of Variables \& List of Explanatory Variables with Expected Procedure of Estimation

\begin{tabular}{ccc}
\hline Variables & Source of Data & $\begin{array}{c}\text { Expected } \\
\text { Sign }\end{array}$ \\
\hline $\begin{array}{c}\text { Dependent Variables } \\
\text { Gross Domestic Product }\end{array}$ & $\begin{array}{c}\text { State Bank of Pakistan(SBP) } \\
\text { World Development Indicator(WDI) }\end{array}$ & + VE \\
\hline Independent Variables & & \\
\hline Consumption Function(CF) & World Development Indicator(WDI) & + VE \\
\hline Inflation (INF) & World Development Indicator(WDI) & + VE \\
\hline
\end{tabular}




\begin{tabular}{ccc}
\hline Employment (EMP) & World Development Indicator(WDI) & -VE \\
\hline $\begin{array}{c}\text { Gross Domestic Saving (GDS) } \\
\begin{array}{c}\text { Gross National Expenditure } \\
\text { (GNE) }\end{array}\end{array}$ & World Development Indicator(WDI) & -VE \\
\hline Qausi Money(M2) & World Development Indicator(WDI) & +VE \\
\hline
\end{tabular}

Descriptive and econometric analysis, Stationarity of data, Unit Root Test, Co-integration analysis, bound test, and Auto-Regressive Distributed Lagged Model (ARDL) used for analysis are used to carry out the analysis as needed. The following procedure should be developed to figure out the solution of estimation. First of all, we discussed the steps that are applied in our model to evaluate and manipulate the data.

\section{Stationarity of Data}

For forecasting, variable stationarity exists when meaning $s$ and variances are constant. And if means and variances of variables do not remain constant then we cannot find the stationarity of the model's variables.

\section{Unit Root Test}

In the unit root test, we cheered our variables at level and 1stalteration. Further in the level, we check at Trend, Trend \& Intercept, and None.

\section{Co-integration Analysis}

We suppose extensive- run connection between variables, while study AutoRegressive Distributed Lagged model. In our analysis we deliberate measurement of dissimilar variables that are statistically substantial.

\section{Auto Regressive Distributed Lagged Model (ARDL)}

In an ARDL model, the following processing can be followed.

$$
\begin{aligned}
=\gamma_{0}+\sum_{i=1}^{p} & \omega_{1 i} \Delta C_{t-i}+\sum_{i=1}^{p} \omega_{2 i} \Delta I N F \\
& +\sum_{i=1}^{p} \omega_{3 i} \Delta E M P_{t-i} \sum_{i=1}^{p} \omega_{4 i} \Delta G D S_{t-i}+\sum_{i=1}^{p} \omega_{5 i} \Delta G N E_{t-i}^{p} \\
& +\sum_{i=1}^{p} \omega_{6 i} \Delta M 2_{t-i}+\sigma_{1} G D P_{t-1}+\sigma_{2} C_{t-1}+\sigma_{3} I N F{ }_{t-1} \\
& +\sigma_{4} E M P_{t-1}+\sigma_{5} G D S_{t-1}+\sigma_{6} G N E_{t-1}+\sigma_{7} M 2_{t-1}+\mu_{1 t}
\end{aligned}
$$




\section{Bound Test}

In the inbound test, we check the value of F-statistics to find out the significance of our selected variables in the model. We then compare the value of upper and lower critical bound values. For this purpose, we use a different level of significance at $\%, 5 \%$, and $10 \%$ levels of statistics.

\section{Results and Discussion}

In the analysis process, we proceed with the following steps that are mentioned below. In this section, we analyze the description and different tests that are used in the analysis process.

\section{Descriptive Analysis}

Descriptive analysis is an analysis of data that is used in our study to judge the statistical description of data that is being used.

\section{Time Series Analysis}

In time series analysis the data is observed of the different periods with different lags. Time series analysis is normally used where data is given in different periods.

Table2

Augmented Dickey-Fuller Test

\begin{tabular}{cccccccc}
\hline & \multicolumn{3}{c}{ At level } & \multicolumn{3}{c}{ At first difference } \\
\hline $\begin{array}{c}\text { variable } \\
\text { s }\end{array}$ & Trend & $\begin{array}{c}\text { Trend and } \\
\text { intercept }\end{array}$ & none & Trend & $\begin{array}{c}\text { Trend and } \\
\text { intercept }\end{array}$ & none & conclusion \\
\hline GDP & -4.092 & -4.770 & -1.325 & & & & Stationary \\
\hline CF & -5.901 & -6.658 & -4.374 & & & & Stationary \\
\hline INF & -4.652 & -4.496 & -2.619 & & & -8.473 & $\begin{array}{c}\text { Non- } \\
\text { stationary }\end{array}$ \\
\hline EMP & & & -8.610 & -8.647 & & stationary \\
\hline GDS & -7.341 & -7.634 & -0.435 & & & -7.839 & $\begin{array}{c}\text { Non- } \\
\text { stationary }\end{array}$ \\
\hline GNE & & & & -7.750 & -7.699 & -6.019 & $\begin{array}{c}\text { Non- } \\
\text { stationary }\end{array}$ \\
\hline M2 & & & -5.963 & -6.052 & & \\
\hline
\end{tabular}

In the above table all we concluded the stationarity of our selected variables which are as follows: domestic growth rate (GDP), employment level (EMP), gross domestic saving, gross national expenditures, quasi money, consumption, and inflation. Augmented Dickey-Fuller Test (ADF) was applied to check the unit root. GDP time series is stationary at a $1 \%$ level of significance at I(0).EMP has the unit root and it is integrated at the asI(1). Likewise, GDP def. and GDS also has unit roots and are stationary at their 1st difference and CF and INF are stationary at level. The 
next step is the co-integration test to check out the connection between our selected variables, such as GDP, CF, EMP, INF, GDS, GNE, and M2 by implying the Bound Test technique on it.

Table 3

Bound Test

\begin{tabular}{|c|c|c|}
\hline Critical value & LCB & UCB \\
\hline $10 \%$ & 1.92 & 2.89 \\
\hline $1 \%$ & 2.73 & 3.9 \\
\hline F-Statistics & & \\
\hline
\end{tabular}

From the given result it is concluded that the value of F-statistics is 4.01 that is greater than Upper Critical Bound(UCB).

Table 4

Long-run Estimate of the Model

\begin{tabular}{ccccc}
\hline Variables & Coefficient & Std.Error & t-statistics & Prob. \\
\hline CF & 0.3299 & 0.1110 & 2.9703 & 0.0060 \\
\hline Inf. & 0.1398 & 0.1124 & 1.2431 & 0.2241 \\
\hline EMP. & -0.5999 & 0.2065 & -2.9040 & 0.0071 \\
\hline GDS & -0.6817 & 0.3686 & -1.8490 & 0.0750 \\
\hline GNE & -1.0250 & 0.4954 & -2.0689 & 0.0479 \\
\hline M2 & 0.2993 & 0.1657 & 1.8061 & 0.0816 \\
\hline C & 127.3207 & 57.4948 & 2.2144 & 0.0351 \\
\hline \multicolumn{3}{|c}{0.5572} \\
\hline \\
Rdjusted R-squared & 0.3832 \\
\hline Prob. (F-statistic) & 0.006 \\
\hline & Durbin-Watsonstats & 2.4425 \\
\hline
\end{tabular}

Here is the long-run relationship of our described variables that are used in the model. Most of the variables have a probability of less than $0.05 \%$, which shows that variables affect the dependent variable. Except for INF which are not less than $0.05 \%$.

Table5

Short-run Estimate of the Model

\begin{tabular}{ccccc}
\hline Variables & Coefficient & Std. Error & t-statistics & Prob. \\
\hline CF & 0.1954 & 0.0495 & 3.9420 & 0.0005 \\
\hline Inf. & 0.1017 & 0.0735 & 1.3841 & 0.1773 \\
\hline EMP. & -0.5505 & 0.2217 & -2.4824 & 0.0193 \\
\hline GDS & -0.5514 & 0.3444 & -1.6012 & 0.1205 \\
\hline GNE & -0.8922 & 0.3404 & -2.6206 & 0.0140 \\
\hline M2 & 0.0425 & 0.1367 & 0.3108 & 0.7582 \\
\hline CointEq(-1) & -0.9998 & 0.1520 & -6.5760 & 0.0000 \\
\hline
\end{tabular}


The short-run co-integration is used to demonstrate the coefficient, Std. Error, t-statistics, and the prob. Of the independent variables. The last value is for CointEq(-1) which also satisfied our terms that the value of coefficient must be negative and the probability must be less than 0.05 . This table illustrates the shortrun coefficient of each independent variable that is selected on ARDL. All the values in the column of probability show that which variably affect significantly. In the short run, Inflation could hardly get the effect of GDP.

Table 6

Serial correlation LM Test

\begin{tabular}{cc}
\hline F-statistic $=3.133$ & Prob. $($ F-statistic $)=0.06$ \\
\hline ObsR-square $=7.77$ & Prob. $($ chi-square $) 2=0.02$ \\
\hline
\end{tabular}

The above table shows the results of correlation in our data. The value of Prob. (F-statistic) which is greater than $0.05 \%$ shows that in our model there is no autocorrelation among variables.

Table 7

Heteroscedasticity Test

\begin{tabular}{cc}
\hline Prob.(C) & T-statistic \\
\hline 0.0002 & 4.17 \\
\hline
\end{tabular}

The above reveals the conclusion that the ARDL technique applies the Heteroscedasticity Test $\mathrm{ARCH}$ to check the hetero among the variables which resulted that our model is also free from heteroscedasticity

\section{Stability Test}

We estimate the CUSUM stability test in the autoregressive distributed lags method (ARDL) to show the stability of the data. Our variables, data are stable because the cumulative sum of recursive residuals CUSUM graph is within the limits of $5 \%$ significance level and cumulative sum of the square of recursive residuals CUSUMSQ graph is also within the limits of $5 \%$ significant.

\section{Plot of Cumulative Sum of Recursive Residuals}

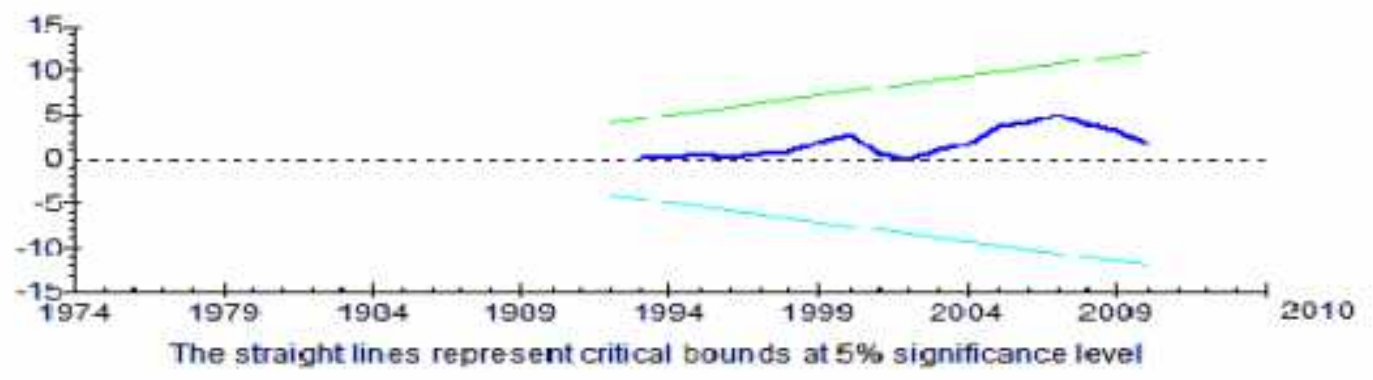




\section{Plot of Cumulative Sum of Squares of Recursive Residuals}

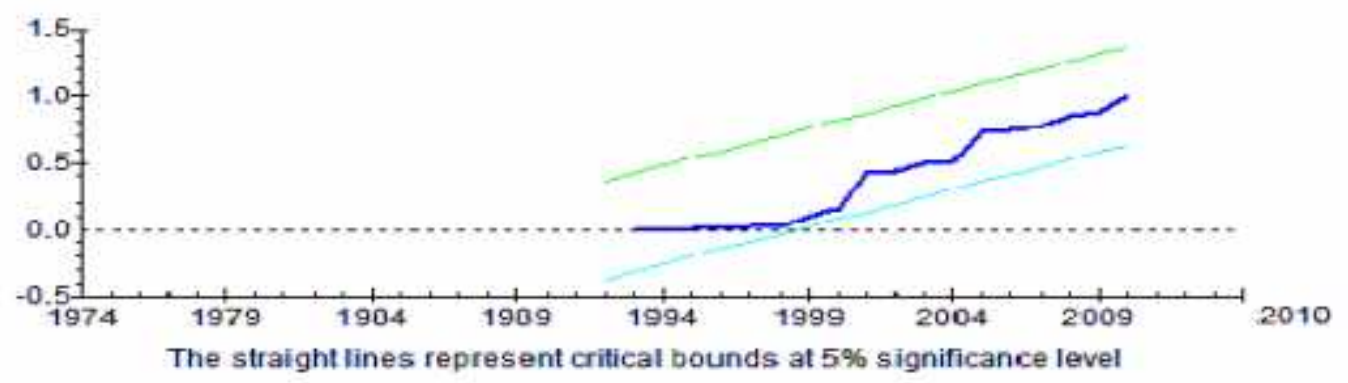

In the above graph, we check the significance of our model by using the CUSUM test. The graph shows the result about CUSUM of squares we check the stability of data by applying this simple technique.

\section{Conclusion and Policy Implication}

From all the above discussion it has resulted that monetary policies have a vital role to encourage and to ensure the growth in an economy. It controls the flow of money to expansionary and contractionary techniques to increase and decrease the flow of money respectively. It controls the money in both ways as in recession or depression by different federal organizations or by the central bank of a nation. Monetary policy is established by the FOMC (the Federal Open Market Committee). It includes members like the president of five keep back banks and the board of directors of governance of the Federal Reserve System. They discussed if different issues in eight meetings held in a year and other gatherings as required. One of the most powerful policymakers was Volcker, along with his followers collectively made up rules and policies. There are some common goals given by both Monetarists and Keynesians and even now days the share also suggested to contribute and achieve Economic growth. The rate of Inflation should be zero (or less than zero approximately ) in an economy.

Monetary policy is established by the FOMC (the Federal Open Market Committee). It includes members like the president of five keep back banks and the board of directors of governance of the Federal Reserve System. They discussed if different issues in eight meetings held in a year and in other gatherings required. One of the most powerful policymakers was Volcker, along with his followers collectively made up rules and policies. There are some common goals given by both Monetarists and Keynesians and even now days the share also suggested to contribute and achieve Economic growth.

The business cycle should be computed in the growth of the economy and its physical forces. The only production can be computed in GDP (Gross Domestic Product). 
Rate of Inflation should be zero(or less than zero approximately) in an economy.

The rate of Gross Domestic Product (GDP) per labor should be increased also with the increase in productivity.

Last but not the least, employment should be increased and physical as well as natural utilization should also be increased to overcome the Inflation rate in an economy. 


\section{References}

Altar, M. (2003). Fiscal and monetary policies and economic growth. SSRN 1102581.

Baghebo,M.\&Stephen,E.T.(2014).MonetaryPolicyandEconomicGrowthinNigeria (1980-2011).AsianEconomicandFinancialReview,4(1),20.

Becker, M. C. \& Knudsen, T. (2002). Schumpeter 1911: farsighted visions on economic development. American Journal of Economics and Sociology, 61(2), 387403.

Chaudhry, I. S. Malik, A. \&F aridi, M. Z. (2010). Exploring the causality relationship between trade liberalization, human capital, and economic growth: Empirical evidence from Pakistan. Journal of Economics and International Finance, 2(9), 175182.

Contessi, S. \& Weinberger, A. (2009). Foreign direct investment, productivity, and country growth: an overview. Federal Reserve Bank of St. Louis Review, 91(2), 61-78.

Dimitrijević, B. \&Lovre, I. (2013).Essay on monetary policy and economic growth. Journal of Central Banking Theory and Practice, 1(3), 111-138.

Fasanya, I. O. Onakoya, A. B. \&Agboluaje, M. A. (2013). Does monetary policy influence economic growth in Nigeria?. Asian Economic and Financial Review,3(5),635.

Gul, H.Mughal, K.\& Rahim,S. (2012). Linkage Between Monetary Instruments and Economic Growth. Universal Journal of Management and Social Sciences, 2(5),69-76.

Hameed, I. (2010). Impact of monetary policy on the gross domestic product (GDP). Interdisciplinary journal of contemporary research in business, 3(1), 1348-

Jain, A. K. (2001). Corruption: A review. Journal of economic surveys, 15(1), 71-121.

Kamaan, C. K. \&Nyamongo, E. M. (2014).The Effect of Monetary Policy on Economic Growth in Kenya. International Journal of Business and Commerce, 3(8), 11.

King, R. G. \& Levine, R. (1993). Finance and growth: Schumpeter might be right. The quarterly journal of economics, 108(3), 717-737.

Levine, R. (2002). Bank-based or market-based financial systems: which is better? (No. w9138). National Bureau of Economic Research.

Lucas, R.E. Jr.(1988), "On the Mechanics of Economic Development", Journal of MonetaryEconomics22,3-42 
Mabrouk, A. \& Hassan, S. M. (2012). Evolution of monetary policy in Egypt: a critical review. The International Journal of Social Science TIJOSS, 4(1).

Masnan, F. Shaari, M. S. \& Hussain, N. E. (2013). Relationship among Money Supply, Economic Growth, and Inflation: Empirical Evidence from Three Southeast Asian Countries. International journal of information, Business, and Management,5(3),83.

Morse, S. (2013). Indices and indicators in development: An unhealthy obsession with numbers. Routledge.

Nouri,M.\&Samimi,A.J.(2011).TheImpactofMonetaryPolicyonEconomicGrowth inIran. Middle-East Journal of Scientific Research,9(6),740-743.

Papademos, L. (2003). The contribution of monetary policy to economic growth. Die Förderung des Wirtschaftswachstums in Europa Fostering Economic Growth, 23.

Qayyum, A. (2006). Money, inflation, and growth in Pakistan. The Pakistan Development Review, 203-212.

Romer, P. M. (1986).Increasing returns and long-run growth. Journal of political economy, 94(5), 1002-1037.

Sherraden, M. S. Johnson, L. Guo, B. \& Elliott, W. (2011). Financial capability in children: Effects of participation in a school-based financial education and savings program. Journal of Family and Economic Issues, 32(3), 385-399.

Twinoburyo, E. N. \& Odhiambo, N. M. (2018). Monetary policy and economic growth: A review of international literature. Journal of Central Banking Theory and Practice, 7(2), 123-137. 